SCHOLARS: Journal of Arts \& Humanities

Volume 2, August 2020, pp. 45-54

[Peer-Reviewed, Open Access, Indexed in NepJOL]

Print ISSN: 2773-7829; e-ISSN: 2773-7837

DOI: https://doi.org/10.3126/sjah.v2i0.35012

Central Department of English

Tribhuvan University

Kirtipur, Kathmandu, Nepal

www.cdetu.edu.np/ejournal/

Theoretical/Critical Essay Article

\title{
Michelle Obama's Becoming as a Political Memoir: A Gramscian Approach
}

\author{
Tara Lal Shrestha, PhD \\ Central Department of English \\ Tribhuvan University, Kirtipur, Nepal
}

\begin{abstract}
When one internalizes the truth that nothing is beyond the politics of hegemony, the counterhegemoinic discourse exists as strategic essentialism. As such, the influence of hegemonic discourses as represented by the dominant group gets transferred to the dominated mass inferior group. Derogatory terms towards racial minorities, to the African-Americans in particular, have been internationalized with generalization. Michelle Obama's 2018 autobiography Becoming unearths such deep-rooted dynamics of dehumanization of minorities persisting in her country where racism enclosed with patriarchy is still dominant in newer forms in everyday life. Indifferent to politics in her early phase of life, she gradually gets metamorphosed into an activist intellectual. She stands along with some critics to defend that America did not enter into the 'postracial era' even after Barack Obama served the White House as the President for two terms. She looks in search of 'organic' intellectuals who assume the integral politicization of a practical intellectual role as the permanent persuader to preserve achieved minority rights in the context of the rise of Donald Trump in American politics. Her memoir, having political febrics, therefore, presents a counterhegemonic essence.
\end{abstract}

Keywords: Hegemony, dehumanization, minorities, activism, intellectuals

\section{Introduction}

Michelle Robinson Obama, who served as first lady of the United States of America from 2009 to 2017 encountered various cracks in her country regarding race relations and minority issues. When Barack Obama was first elected as the US President, various commentators naively declared that USA was entering a "postracial” era, in which skin color and minority issues would no longer matter. Michelle Obama through her memoir Becoming shows how wrong the critics had been in their optimism about the downing of 'postracial' America. She presents dynamics of dehumanization and racialization being continued in America to impact global black experience and condition of minorities. The bildungsroman story of Michelle Obama, which presents her development of various aspects of life, helps to understand persisting dynamics of dehumanization of minorities in America and beyond.

Michelle Obama in her memoir looks at her life back and forth. Her aspirations in her earlier phase of life were simple. Her family was her world, the center of 
Michelle Obama's Becoming as a Political Memoir: A Gramscian Approach 46

everything. Her father would go to work everyday dressed in the blue uniform of a city laborer, but at night he would show her what it meant to love jazz and art. At home, she continued to work on her own progress as a musician. Her father would take her out for an aimless drive. Music was a means of becoming to her and others. From her bedroom window she could observe most of the real world happening outside. Racism was rampantly visible in her community. Her parents taught her the bitter truth of life. She writes,

As we grew, we spoke more about drugs and sex and life choices, about race and inequality and politics. My parents didn't expect us to be saints. My father, I remember, made a point of saying that sex was and should be fun. They also never sugarcoated what they took to be the harder truths about life.... The color of our skin made us vulnerable. It was a thing we'd always have to navigate. (25)

Michelle Obama recalls her moments of learning from the first school, home. Her parents are her first good teacher to her. Politics of remembering, what to and what not to remember, matters a lot in self-referential text. She looks honest to tell about her roots. Her father was from the South Carolina Low Country, as she recalls, "where thousands of slaves once labored on vast plantations, harvesting crops of rice and indigo and making their owners rich” (37). She is proud of her slave-family roots. Her grandfather was the grandson of slaves. She respects her father, who was not only a black and from poor family but also came of age during the Great Depression. Such a naïve girl had to move away of home. She had to encounter bigger world face to face outside. Chicago was a much bigger city for her. Through the window, she would observe a long slow view of the South Side. She got the opportunity to go beyond Chicago. The Princeton world, where she went first time in the age of 17 was an alien world for her. She was nervous when she realized that she was nothing there as a black girl. She writes, "Princeton was extremely white and very male.... At Princeton, it seemed the only thing I needed to be vigilant about was my studies" (71-72). For her, the South Side was something entirely different from what got shown on TV. To her, it was home. At Princeton, she learned for the first time what it felt like to be the only black woman in her classroom. The outside bigger world was more racist as well as sexist. The very white male Princeton world forced her to think how hard it is to becoming equal citizen. The sense of dehumanization is one of the key causes of converging her into an activist intellectual, though she didn't like politics. She writes, "There were days, weeks, and months when I hated politics” (xi). Despite her indifference to politics, she spent eight years in the White House. Then it was over as she confesses, “There's a lot I still don't know about America, about life, about what the future might bring” (x). She has better realized now that growing up is infinite and her struggle against white male supremacy is more publicized. She has realized that becoming is a process, a more frazil journey particularly to the minorities within hegemonic power structures.

This paper aims at exploring the subtle layers of hegemonic structures deeply rooted in the United States of America with reference to Michelle Obama's memoir Becoming. Gramscian notion of hegemony, subaltern and role of intellectuals is the key theoritical approach used in this research. Regarding the structure of the paper, it firstly covers the overall development of Obama's life, her transitional stages and her transformation from an ordinary individual to an activist intellectual with reference to 
her memoir Becoming as documented in the introductory section. Secondly, it draws the insights of hegemony, subaltern and role of intellectuals from Gramscian approach in particular. Thirdly, it covers the historical contexts of dehumanization of AfricanAmericans and its aftershocks even in the so-called 'postracial' era in the United States of America. Obama's memoir is a remakable space to speak on the politics of hegemony and dehumanization of the subaltern in the United States. Life events of Obama offer ample reference in order to analyze the politics of layers of hegemony.

\section{Hegemony and American Politics}

This paper uses the notion of hegemony and dehumanization of the subaltern through Gramcian approach. Antonio Gramsci's concept of hegemony, the "consent of the ruled to be ruled" (156) is apt to link with Michelle Obama's academic as well as political activism. Human history is never been beyond the influence of the power hegemony of dominant groups. The elitist structure of feudalism has been stretched further to early capitalism, capitalism and late-capitalism. Colonial and imperialist cultures are still dominant in various latent forms. Universalizing Eurocentric ideologies are still alive and active in non-western regions. There are layers of power hegemony from domestic to global levels. Elitist structures are rampantly exercised in the pretention of acting to the subaltern groups. Nothing is beyond the grip of the power hegemony of ruling groups.

Recently, hegemony is not only the political, economic or military predominance/control of one state of others. The hegemony through consent is more sublte and complex one that lead the subaltern under layers of hegemonic life. The more complex predicament of the minorities automatically demands 'organic' intellectuals as permanent persuaders, who have influencing capacity to alter the common sense.

Michelle and Barack Obama influenced each other. She turns to be a writer, because, she recalls, “...I suppose, from Barack, who viewed writing as therapeutic and clarifying and had kept journals on and off over the years" (130). Barack Obama, as she called him, is "the fact guy" (155). After she got married to an eclectic, multicultural and workaholic over-committer Obama, she became a senator's wife as well as working mother being involved indifferently in political activism. But she was so much scared, as she write, "Barack was a black man in America, after all”, and she further writes, "I didn’t really think he could win” (226). Furthermore, Barack Obama's safety was another issue. Her sense of fear is touchier. She writes,

So many of us had been brought up with assassinations on the news at night. The Kennedys had been shot. Martin Luther King Jr. had been shot. Ronald Reagan had been shot. John Lennon had been shot. If you drew too much heat, you bore a certain risk. But then again, Barack was a black man. The risk, for him, was nothing new. He could get shot just going to the gas station. (242)

Barack Obama could be killed anywhere was a common thoughts passing through her mind during that time. Despite the fact that he was sympathetic to white workers, in David A. Hollinger's words, "who tended to blame affirmative action for their problems...urged Americans to look upon inequality in historical terms, and reached out across the black-white coluor line, confirming his image as a black politician who did not offer a black-centered message” (1037). Politics was still not her business. Passing 
through a high sense of insecurity, on November 4, 2008, Michelle Obama had cast her vote for Barack Obama and moved to meet his Grandma. Then, everything was new. The two words "first" and "black" came along to be attached with the title 'First Lady'. She was all of a sudden in a huge place, the White House, as she narrates, with 132 rooms, 35 bathrooms, and 28 fireplaces spread out over six floors. It came to be very tough to appear to the public. It seemed, to her, like to live in a fancy hotel without others. Heaviness in each movement and too much controlled were everyday reality in the White House world. Valerie Loichot observes, “Obama as a symbol represents a particularly compelling example of the untranslatability of race since, as the new head of state of a powerful Western Nation, and as an immediately recognizable figure in global consciousness he cannot be dismissed as a negligible exception” (78). On the one hand it was claimed as 'postracial' era and on the other hand racism was being transformed into newer forms. Hatred and aggression on racial minorities had increased more opponents to the Black activist as Johnson, Dowe and Fauntroy write,

President Obama like past presidents has had to face opponents and critiques by the media, politicians, and citizens; but has also had to content with opposition and critiques that have played on race and racial stereotype; it revealed that unspoken desire for retribution by whites who are not agreeable to the idea of an African-American president.

Different Media depicted Barack Obama's rise as a symbol of a "postracial," "postblack” or "postethnic" era, which was, in David A. Hollinger's words, "a far reaching challenge to identity politics" (1033). Barack Obama had hardly offered himself as the candidate of a particular ethno-racial group and millions of white voted to him. There is also a line of argument as Hollinger has hinted that circumstances will push Obama back and forth between images of "more black than we thought" and "not as black as we thought" (1037). All sorts of minority groups cheered up on the rise of Obama. Nahid Afrose Kabir's excitement is notable here, "Oh, in the symbolic sense, absolutely, it is a big change to have a black president, I think there's a change of attitude more than there's a change of policy" (148).

Actually, Barack Obama's nomination for the presidency in American brought the issue of dehumanization of the racial-ethnic and other minorities at the core of sociopolitical as well as academic discourses. The counter-hegemonic academics and activism offered space to the activist intellectuals like Michelle Obama to come up with such a bold memoir Becoming. Her autobiography is one of the living histories of studying layers of hegemony dominant in American politics.

\section{A Memoir of Dehumanization and Resistance}

Subaltern consciousness is a resistance consciousness. The persisting dehumanization leads the oppressed towards the way of resistance though most of the subversive actions of the subaltern turn to torcher and trouble. Those who get existence in the mainstream forget their intellectual role as permanent persuader. Obama looks serious enough about it. For instance, shortly after Barack Obama was elected, Vogue proposed Michelle Obama to put her on the cover of the magazine. Her team debated whether it would make her seem frivolous or elitist but they decided it would matter every time a woman of color showed up on the cover of mainstream magazine. Barack 
Obama's presence in the White House had been celebrated by millions of Americans, but ironically his victory also caused to a reactionary sense of fear and resentment because the hatred was old and deep and as dangerous as ever. Americans, obsessed over the threat of terrorism, were overlooking the racism and tribalism that were tearing the nation apart. Gramscian notion of "the production of consent", as Chris Barker argues, "implies popular identification with the cultural meanings generated by the signifying practices of the hegemonic texts" (11). For Gramsci, hegemony implies a situation where a 'historical bloc' of ruling-class functions exercise social authority and leadership over the subordinate classes, which is achieved through a combination of force and consent as well. In the words of Grmasci,

The normal exercise of hegemony on the classical terrain of the parliamentary regime is characterized by the combination of force and consent, which balance each other reciprocally without force predominating excessively over consent. Indeed, the attempt is always to ensure that force would appear to be based on the consent of the majority expressed by the so-called organs of public opinion newspapers and associations. (80)

Manufacturing the consent to exercise hegemony upon the subaltern persist for centuries. For Gramsci the hegemony through consent is more subtle and long-lasting then the hegemony through force. The 'common sense' is an established ideology of hegemony. It persists to be the legacy of dehumanization directed to historically marginalized groups of people. So, Gramsci advocates the need of 'organic' intellectuals, unlike traditional intellectuals, who could remain intellectuals for the oppressed class. As ruling class ideologies are always pervasive, dehumanization gets established as 'common sense' as Gramsci argue, which was publicly seen after Obama ascended to the White House. The black people were generalized and dehumanized by Russian politicians by terming Barack and Michelle Obama as mammalian apes (or, monkeys) (qtd. in Simon Raymond 262). The long been established ruling groups, who hold on the hegemonic power, subsequently began to concentrate on the production of ideological instruments, the favorable texts for themselves in all the dominant power sectors. That hegemonic mode of production affects all the socio-political, economic and cultural practices. So, 'organic' intellectuals as permanently active persuaders have to be engaged to form the basis for a new society. Joe Cleffie reviews Gramsci's notion of permanent persuaders from the viewpoint of Peter Thomas as,

These permanently active persuaders find their intellectual resources not in the 'perennial questions of philosophy' but precisely in their organic integration with the masses, in a reciprocal relationship of 'democratic pedagogy' in which those intellectuals with the social function of an intellectual are at least as often 'the educated' as 'the educators.' They are intellectuals who are 'organically the intellectuals of these masses..." (508)

The rise of Obama in US politics had formulated remarkable stories in human history. The race factor of Obama really played both positive and negative roles in media coverage that influenced to the mass of voters. Various groups of people participated in discourses related to Obama's rise. A student in political science said, "Yes, the race did matter in Obama's election. Not the black race. White race. Obama wanted every race- 
Michelle Obama's Becoming as a Political Memoir: A Gramscian Approach 50

white, black, Hispanic, Latino, Asian and everyone else...to vote for him” (qtd. in Murty et al. 34). There was politics of neutrality. But, Obamas were more concerned to minorities as activist intellectual. After holding the position of the first lady, she began to deliver speeches to motivate youths, women and minorities urging them not to lose hope; she encouraged them to overcome fear. She, however, lived fearful life in the White House. Nor could she be fearless after she left the White House. The rise of Trump has made her more fearful, which acknowledges, as Gregory D. Smithers presents references from Obama, “...'color blindness' and 'postracial' must not be used uncritically... because race and racism continue to shape the lives of millions of Americans” (1). Therefore, using blanket approach while addressing the subtle issue of racism is problematic. The hasty claim of 'postracial' era is ambivalent to Michelle Obama; her memoir presents many instances.

Barack Obama was charged Islam-friendly. He was addressed with extended middle name, as Barack Hussein Obama. Osama bin Laden was declared as the king of terror. Ultimately, Laden had been killed. It was news of celebration in White House. According to Marc Lynch, "Barack came to office intending to defeat al Queda with lighter footprint, through drone strikes, partnerships with local allies, and the cultivation of more moderate Islamist groups....Al Qaeda lost political and organizational ground across the region, culminating in the May 2011 killing Laden” (26). Barack was the first person to share the death news of Laden to Michelle Obama. She writes, "Barack had taken an enormous risk- one that could have cost him his presidency-and it had all gone okay" (363). She, however, realized that nobody's death would ever replace a life. She writes, "I'm not sure anyone's death is reason to celebrate, ever. But what America got that night was a moment of release, a chance to feel its own resilience" (364). Barack Obama won again because, in her words, he had won the hearts of young people, minorities and women.

After Michelle Obama left the White House, she expresses in her memoir that it is a sense of relief. But it was tough to her since Trump announced his candidacy and he called "rapists" to Mexican immigrants. Trump further said, as she quotes, "the losers were running the country" (400). The political statements Trump delivered one after another during his campaign made her upset. On the day Trump clinched the Republican nomination for president, she was in New Mexico speaking to a class of Native American students. She confesses, the deeper she got into the experience of being first lady, the more emboldened she felt "to speak honestly and directly about what it meant to be marginalized by race and gender” (405). She writes, "I knew invisibility. I'd lived invisibility. I came from a history of invisibility. I liked to mention that I was the greatgreat-granddaughter of a slave named Jim Robinson, who was probably buried in an unmarked grave somewhere on a South Carolina plantation” (405). Racial cracks were visible during her activism as the first lady. Elite white world was hesitant to accept her merits. She was busy giving commencement speeches. But elite educational institutions run by whites were not ready to welcome her as commencement speaker. She writes,

For me, giving commencement speeches was an important, almost sacred springtime ritual. Each year I delivered several of them, choosing a mix of high school and college ceremonies, focusing on the sorts of schools that normally didn't land high-profile speakers. Princeton and Harvard, I'm sorry, but you're fine without me. (404) 
Michelle Obama’s Becoming as a Political Memoir: A Gramscian Approach 51

Her feeling of 'Othering' through educational institution echoes Gramsci's notion on education. In his view, "If our aim is to produce a new stratum of intellectuals...from a social group which has not traditionally developed the appropriate attitudes, then we have unprecedented difficulties to overcome" (43). In the mode of organic intellectuals as permanent persuaders, in Stephen Brookfield's words, she was "working in solidarity with those who share a common oppression..." (115). The very institutions, Princeton and Harvard, where she studied did not welcome her. It was her dream, most probably, to be there and speak with emotional and academic attachment. Feeling herself not being among the high profile speakers, she expresses her emotional aggression, 'Princeton and Harvard, I'm sorry, but you're fine without me.'

Obama's Becoming unfolds series of unpleasant feelings of racial dehumanization. Trump, who among other things demeaned minorities with expressed contempt, exists as a sexiest white in her memoir. The charges to each other were publicized as "When they go low, we go high" (407). She even articulated her rage in front of crowd, "This is not normal. This is not politics as usual. This is disgraceful" (409). In July 2016, she had campaigned in support of Hillary Clinton, who was the first woman to win a major political party's presidential nomination in the USA by saying, “...I wake every morning in a house that was built by slaves, and watch my daughters...playing with their dogs on the White House lawn...take for granted that a woman can be president of the United States" (410). Her sense of confidence to see a (white) woman president of the United States could not be sustained. She got confirmed news, "American voters had elected Donald Trump. She expresses her feeling of frustration in her memoir, "The next day, I woke to a wet and dreary morning...I couldn't help but interpret it as funereal.... And I will always wonder about what led so many women, in particular, to reject an exceptionally qualified female candidate and instead choose a misogynist as their president” (411). Her team in the White House was made up largely of women and minorities, including several who came from immigrant families. In her words, "Many were in tears, feeling that their every vulnerability was now exposed" (412). She wanted to make them feel that "everything was not lost...we were, would always be, the first black one" (412), and in the White House they had hung "a stunning yellow, red, and blue abstract painting by Alma Thomas - Resurrection which became the first work of art by a black woman to be added to the White House's permanent collection" (413). After she left the White House, she is calculating how Trump has caused to doubt and fear one another. Trump era in the US, for her, is the negation of hasty claim of critic who naively declared, after the victory of Barack Obama, that USA entered into a 'postracial' era. The end of racism, in the word of Franz Fanon, in 'the white world' $(88,103)$ is still a dream as Farah Jesmine Griffin writes, "We've come a long way, baby, but we still got a long way to go" (132). Griffin writes, We do not live in a post-racial time. In fact, to use the term is lazy for him because, in his words, we do occupy a historical movement in which "race and racism operate differently than they have in the past....We are witnessing the death of an epoch of white supremacy. All around us we experience its dying gasp - a desperate, dangerous gasp. But white supremacy is an old man who will not go gently into that good night. (133) 
Michelle Obama's Becoming as a Political Memoir: A Gramscian Approach 52

According to Griffin, "racism will continue to find breath in elements of the Far Right, in the thinking of many mainstream white Americans, in other racial and ethnic groups, and, unfortunately, in far too many black people around the world. Nor we are at the "end of the African American narrative" (33). In Ashraf M. Esmall's claim, "Beyond traditional racism, neo-racism justifies discrimination on the basis of cultural difference or national origin rather than by physical characteristics alone and appeals to "natural" tendencies to preserve group cultural identity - in this case the dominant group.

Underlying neo-racism are notions of cultural or national superiority and an increasing rationale for marginalizing or assimilating groups in a globalizing world” (66).

Barack Obama's mixed ancestry itself generates some sort of new uncertainty about racism. He was descended from white single mother and black father, who went back Kenya. He knew pain of stereotypes on whites as well. However, his immigrantoriginating blackness existed as a space for creating discourses of dehumanization. Antonio Gramsci, who theorized and demanded the integral politicization of the intellectual role as the permanent persuader, argues the role of 'organic' intellectual or activist, which is more conceived not as a free and disinterested search for mere truth; for him, 'the intellectual must cease to be mere seeker of truth and be transformed into a politician, an organic party leader'; s/he must become 'actively involved in practical life as a builder, organizer, and permanent persuader'. While reading Obama's memoir Becoming, an affirmation for permanent persuader booms in such a way that ultimately she, a former non-political person, comes to be a political activist intellectual. He tried not to raise issues of race during his service in the White House. His rise in US politics allowed some Americans to mistakenly believe that race does not matter anymore. But, as Thabiti Asukile views, "Racism is endemic in the US and is never going away" (42). For Michelle Obama too, who had been labeled by her opponents as 'an unpatriotic, angry black woman', race still matters; minority issues still matters. The "consent of the ruled to be ruled" in Gramscian notion is still active that affirms ultimately a need of activist intellectual as permanent persuader to preserve achieved minority rights. As Gramsci conceptualized, she has tried to play role of an activist intellectual emerged "organically" from subordinated class or group. As Bolaria and Hier argue, she plays role of "Permanent persuaders as a special kind of intellectual leader defined by their ability to influence and inspire large numbers of minorities on the basis of experience, shared suffering, and charisma, rather than formal characteristics such as education or occupation” (79).

Addressed to Barack Obama as "Wicked Black Monkey," "Hands Down, Obama Is the Worst President since WWII," "Obama: Worst President Ever," "Has Done Zero for Black People” type of stereotyping titles appeared in the verge of Obama era, dehumanizing on the basis of race and ethnicity still influence the exercise leadership. Leaders of minorities still embrace their minority identity while being dehumanized by dominant group. The role of 'organic' intellectuals as Michelle Obama presents practically in her memoir Becoming is impressively noteworthy in the global as well as local contexts.

\section{Conclusion}

Michelle Obama's memoir Becoming is a counter hegemonic political memoir. The autobiography depicts her various aspects of life but more interestingly the 
transformation of Obama from ordinary individual who does not like politics in the beginning of her career to becoming activist intellectual is noteworthy. Through her eloquent expression, her memoir unearths subtle layers of the hegemony of the dominant class fortified by deep-rooted racism inclined with patriarchy persisting even in the socalled 'postracial' era. The memoir also opens ways for resistance against the deeprooted politics of dehumanization of the minorities in the United States of America. As Obama gradually transforms into an active political activist, her autobiography affirms for an interminable political activism to save subaltern consciousness of resistance in the local as well as global context. Her life events of transition and transformation inclined with political career of Barack Obama are a living history of counter hegemonic discourses, one of the best forms of academic as well as political activism to alter the persisiting dynamics of dehumanization of minorities. Her autobiography is a proof that the United States of America did not enter into 'postracial' era even after Barack Obama served the White House as the President for two terms, which appealed Michelle Obama to be transfigured into an activist intellectual as a permanent persuader. The political circumstances of the United States of America compels her to be metamorposized in politicization of her life in her later phase of career. The counterhegemonic essence of her autobiography is an inspiration to the minorities, a daring discourse to unfold the subtle layers of hegemony.

\section{Works Cited}

Asukile, Thabita. "The Barack Obama New Era: Race Matters More Than Ever in America.” The Black Scholar, vol. 38, no. 4, Winter 2008, pp. 41-43.

Barker, Chris. Cultural Studies: Theory \& Practice. $3^{\text {rd }}$ ed., Sage, 2008.

Bolaria, B. Singh and Sean Patrick Hier, editors. Identity and Belonging: Rethinking Race and Ethnicity in Canadian Society, Canadian Scholars Press, 2006.

Brookfield, Stephen. The Power of Critical Theory for Adult Learning and Teaching. Open UP, 2005.

Cleffie, Joe. "Rescuing Gramsci from His Misinterpreters.” International Socialist Review (ISR), Issue 93, https://isreview.org/issue/93/rescuing-gramsci-hismisinterpreters.

Cooper, Brittney. "A'n't I a Lady?: Race Women, Michelle Obama, and the EverExpanding Democratic Imagination." MELUS, vol. 35, no. 4, 2010, pp. 39-57. Jstor, https://www.jstor.org/stable/25759557?

Esmail, Ashraf M. et al. “The Art of Killing a Dream.” Gender \& Class, vol. 20, no. 3-4, (2013), pp. 64-79, published by Jean Ait Belkhir, Race, Gender \& Class Journal, 23-11-2019 06:02 UTC.

Fanon, Frantz. Black Skin, White Mask. Editions du Seuil, 1952.

Foucault, Michel. "Truth and Powers". Critical Theory since Plato, edited by Hazard Adams, Harcourt Brace, 1992, pp. 1134-1145

Gramsci, Antonio. Selections from the Prison Notebooks, edited and translated by Quintin Hoare and Geoffrey Nowell Smith, Orient Black Swan, 1996.

---. The Prison Notebooks: Selections edited and translated by Quintin Hoare and Geoffrey Nowell Smith, Lawrence and Wishart, 1973. 
Griffin, Farah Jesmine. "At Last...?: Michelle Obama, Beyonce, Race \& History.” Daedalus, vol. 140, no. 1, Race in the Age of Obama, Vol 1 (Winter 2011), pp. 131-41. MIT Press, 20-11-2019 01:21 UTC.

Hollinger, David A. "Obama, the Instability of Color Lines, and the Promise of a Postethnic Future.” Callaloo, vol., 31, no. 4. (Fall, 2008), pp, 1033-37, The John Hopkins UP. 21-11-2019 05:12 UTC.

Johnson, Tekla Ali et al. "One America? President Obama's Non-Racial State." Race, Gender \& Class, vol., 18, no. 3-4, 2011, pp. 135-149. Jstor, https://www.jstor.org/ stable/43496838?.

Kabir, Nahid Afrose. "Barack Hussein Obama and Young Muslims’ Political Awareness.” Young American Muslims: Dynamics of Identity, Edinburg UP, 2013.

Kaplan, Erin Aubry. "Michelle Obama’s Rules of Assimilation." The New York Times, Feb., 24, 2019.

Lynch, Marc. "Obama and the Middle East: Rightsizing the U.S. Role.” Foreign Affairs, vol. 94, no. 5, (SEP/OCT 2015), pp. 18-27. Published by Council on Foreign Relations, 23-11-2019 06:04 UTC.

Loichot, Valerie. “Creolizing Barack Obama.” American Creoles, edited by Martin Munro and Celia Britton, Liverpool UP, 2012. Jstor, 20 NOV 2019.

"Michelle Obama Keynote Address at the Democratic National Convention." YouTube. Uploaded by C-SPAN, 25 Aug. 2008, https://www.youtube.com/watch?v=Linx1 XLUbYo

Murty, K.S., et al. "How did Obama Win His Second Term? Minority Students' Perceptions and Reactions...” Race, Gender \& Class, vol., 21, no. 1-2, (2014), Jean Ait Belkhir. Accessed 23-11-2019 06:03 UTC. Obama, Michelle. Becoming. Penguin Random House, 2018.

Raymond, Simon. "Dehumanization, Racial Minority and Female Leadership: An Analysis of Global Trends.” Advances in Applied Sociology, vol. 6, no. 8, 2016, 261-269. https://www.scirp.org/pdf/AASoci_201608191404 4874.pdf

Rowland, Robert C. and John M. Jones. "One Dream: Obama, Race and the American Dream.” Rhetoric and Public Affairs, vol., 14, no. 1, (Spring 2011), pp. 125-54) Michigan State UP. Accessed 23-11-2019 06:03 UTC.

Smithers, Gregory D. "Barack Obama and Race in the US: A History of the Future." Australasian Journal of American Studies, vol., 28, no. 1, (July 2009), pp. 1-16. Published by ANZASA, 23-11-2019 06:04 UTC.

Taylor, Keeanga-Yamahtta. "Succeeding While Black Boston Review.” Boston Review, March 13, 2019.

Thomas, Peter. The Gramscian Moment: Philosophy, Hegemony and Marxism. Haymarket Books, 2011. 